\title{
ADENOSINE RECEPTOR INTERACTIONS ALTER CARDIAC CONTRACTILITY IN THE RAT HEART.
}

\author{
Roselyn B Rose'Meyer \\ School of Medical Sciences, \\ Griffith University, Queensland, Australia, 4222
}

Dr Roselyn Rose'Meyer

School of Medical Sciences

Griffith University

Gold Coast Campus

Queensland, Australia, 4222

Tel. 61755528938

Fax 61755528908

E-mail address: r.rosemeyer@griffith.edu.au 


\section{SUMMARY}

The effect of an adenosine (Ado) $A_{2}$ receptor agonist, $\mathrm{N}^{6}$-[2-(3,5-dimethoxyphenyl)-2-(2methylphenyl)-ethyl]adenosine (DPMA) on $\mathrm{AdoA}_{1}$ receptor mediated negative inotropic responses was investigated in rat heart. Hearts from male Wistar rats (250-350g) were perfused with Krebs-Henseleit solution at constant flow in non-recirculating Langendorff mode. Hearts were paced at $5 \mathrm{~Hz}$ (5 ms duration, supramaximal voltage) via ventricular electrodes. After 30 mins equilibration (R)- $\mathrm{N}^{6}$-phenylisopropyl adenosine (R-PIA) concentration-response curves were acquired in the absence or presence of DPMA. R-PIA induced concentration-dependent decreases in triple product (HR x left ventricular

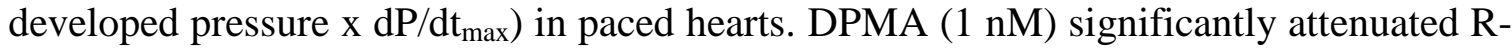
PIA induced decreases in triple product, with a shift in $\mathrm{pEC}_{50}$ from $8.0 \pm 0.51(\mathrm{n}=9)$ in control hearts to $6.63 \pm 1.03(\mathrm{n}=5)$ in treated tissues $(\mathrm{P}<0.05)$. The $\operatorname{Ado}_{2 A} \mathrm{R}$ antagonist 8-(3-chlorostyryl) caffeine $(1 \mu \mathrm{M})$ and the adenylyl cyclase inhibitor cis- $\mathrm{N}-(2-$ phenylcyclopentyl)-azacyclotridec-1-en-2-amine hydrochloride (MDL12330A, 100nM) reversed the effect of DPMA on $\mathrm{AdoA}_{1} \mathrm{R}$ mediated negative inotropic actions while the ado $\mathrm{A}_{2 \mathrm{~B}} \mathrm{R}$ inhibitor (alloxazine, $3 \mu \mathrm{M}$ ) had no effect on DPMA activity. The results show that stimulation of $\operatorname{Ado}_{2} R$ attenuates $A_{d o} A_{1} R$ dependent reductions in inotropic state. The adenosine receptor sub-type involved appears to be the $\operatorname{Ado}_{2 \mathrm{~A}} \mathrm{R}$, and its action involves stimulation of adenylyl cyclase activity.

Key Words: Adenosine, rat heart, cAMP, contractile function 


\section{INTRODUCTION}

Endogenous adenosine affects many aspects of cardiac function due to activation of the adenosine $A_{1}, A_{2}$ and $A_{3}$ receptor (AdoR) subtypes. The adenosine receptor subtypes are found on different regions of the heart. Ado $A_{1}$ Rs are located predominantly in cardiomyocytes where they exert direct inhibitory effects on chronotropy, dromotropy and inotropy $(1,2)$. The physiological effects of adenosine mediated by $\mathrm{AdoA}_{1} \mathrm{R}$ act to reduce the oxygen demand of the heart, thereby reducing myocardial ischaemia-reperfusion injury (3). The Ado $R_{2 A} R s$ and $A d o A_{2 B} R s$ are mainly located on the endothelium and vascular smooth muscle with a low density of ado $\mathrm{A}_{2 \mathrm{~A}} \mathrm{R}$ found on ventricular myocytes (1, $2,4,5)$.

In rat ventricular myocytes, Ado $_{1} \mathrm{R}$ mediated negative inotropic actions are associated with activation of inward rectifying $\mathrm{K}^{+}$current $\mathrm{I}_{\mathrm{K}(\mathrm{Ado})}$ and inhibiting isoproterenol stimulated L-type $\mathrm{Ca}^{2+}$ current (6). AdoA ${ }_{2}$ Rs increase levels of intracellular cAMP via a pertussis-toxin insensitive Gs protein $(7,8)$.

Interestingly, interactions between adenosine receptors in the cardiovascular system have been reported. For example, deletion of $\mathrm{Ado}_{3} \mathrm{Rs}$ augments $\mathrm{Ado}_{2 \mathrm{~A}} \mathrm{R}$ induced vasodilation in murine hearts (9). Other studies have demonstrated that $\mathrm{AdoA}_{1} \mathrm{R}$-mediated electrophysiological effects may be modulated by myocardial $\operatorname{Ado}_{2} \mathrm{R}(10,11)$.

In the chick ventricular heart cells both subtypes of $\mathrm{AdoA}_{2} \mathrm{R}$ 's have been demonstrated to have greatly different affinities for NECA, coexist and are coupled to the same positive inotropic cardiac responses (12). Furthermore, there is recent evidence of $\mathrm{AdoA}_{2} \mathrm{R}$ mediated modulation of the "indirect" anti-adrenergic effects of Ado $_{1}$ Rs (13). In rat 
cardiac tissues both $A_{d o} A_{2 A} R$ and $A_{d o} A_{2 B} R$ are expressed $(14,15)$. Little work has been published on the role of $\mathrm{Ado}_{2 \mathrm{~B}} \mathrm{R}$ in modifying the actions of $\mathrm{AdoA}_{1} \mathrm{R}$ in the heart.

The aims of this study were to examine the impact of $\operatorname{Ado}_{2} \mathrm{R}$ activation on $\mathrm{AdoA}_{1} \mathrm{R}$ mediated inotropic responses, to determine the $\mathrm{Ado}_{2} \mathrm{R}$ subtype involved in modifying $\mathrm{Ado}_{1} \mathrm{R}$ induced cardiac actions, and to establish whether cAMP is a second messenger system involved. 


\section{METHODS}

\section{Animals}

Male Wistar rats (250-350 g) were obtained from the central animal house located at the University of Queensland. They were housed in a room maintained at an ambient temperature of $23 \pm 2{ }^{\circ} \mathrm{C}$ with a twelve hour light-dark cycle. The rats had free access to food and water at all times. The conduct of all experiments conformed to the guidelines for animal experimentation as determined by the National Health and Medical Research Council of Australia and approved by the Griffith University Animal Experimentation Ethics Committee.

\section{Isolated perfused rat hearts}

Rats were anaesthetised with pentobarbitone (60 mg/kg, intraperitoneally). Rat hearts were perfused in the non-recirculating Langendorff mode based on a method described by Harrison et al., (16). Briefly, hearts were rapidly excised and immersed into ice-cold Krebs-Henseleit solution containing (in $\mathrm{mM}$ ): $\mathrm{NaCl} 118, \mathrm{KCl}$ 4.7, $\mathrm{CaCl} 2$ 1.75, $\mathrm{MgSO} 4$ 1.2, glucose 11, EDTA 0.5 and NaHCO3 25, pH 7.4. The aorta was cannulated and heart perfused with Krebs-Henseleit solution gassed with 95\%O2 and 5\% CO2 and kept at $37^{\circ} \mathrm{C}$. Ventricular fluid accumulation was prevented by inserting a small piece of polyethylene tubing through the apex of the left ventricle to drain the cavity and ascertain aortic valve patency. A water-filled latex balloon was then introduced into the left ventricle and connected to a pressure transducer (Gould P23-ID, Oxnard Ca). Enddiastolic pressure was adjusted to $4-8 \mathrm{mmHg}$ by inflating the balloon. Ventricular pressure and heart rate was monitored continuously on a MacLab data acquisition system 
(ADInstruments, Castle Hill, Australia). Coronary perfusion pressure was measured using a pressure transducer connected to a water filled probe inserted into the side arm of the aortic cannula and was recorded using the Maclab data acquisition system. The left ventricular pressure signal was electronically differentiated to measure $\mathrm{dP} / \mathrm{dt}_{\max }$. Tissues were equilibrated for 30 mins prior to experimentation. For inotropic studies, electrodes were attached to the ventricles and paced at $5 \mathrm{~Hz}$ ( 5 ms duration, supramaximal voltage) using a 611 Stimulator (Phipps and Bird Inc, Richmond, VA, USA). To determine myocardial inotropic function a triple product was calculated to incorporate developed pressure and the speed of contraction as follows: HR x Peak systolic ventricular pressure (PSVP) $\mathrm{x} \mathrm{dP/dt}$ max. As calculation of the triple product results in a very large value ie $\left(300 \times 100 \times 2000=6 \times 10^{7}\right)$ all decreases in triple product values $\left(\mathrm{TP}_{\mathrm{R}}\right)$ were shown as a percentage reduction of the paced triple product value prior to the R-PIA concentrationresponse curve $\left(\mathrm{TP}_{\mathrm{C}}\right)$ as follows; $\left(\mathrm{TP}_{\mathrm{C}}-\mathrm{TP}_{\mathrm{R}}\right) / \mathrm{TP}_{\mathrm{R}} \times 100$.

During equilibration, hearts were perfused at a constant pressure of $80 \mathrm{mmHg}$ to allow adequate perfusion of myocardial tissues. For experiments studying the negative inotropic effects of (R)- $\mathrm{N}^{6}$-phenylisopropyladenosine (R-PIA, $0.1 \mathrm{nM}-10 \mu \mathrm{M}$ ) and $\mathrm{N}^{6}$ [2-(3,5-dimethoxyphenyl)-2-(2-methylphenyl)-ethyl]adenosine (DPMA, $0.1 \mathrm{nM} \mathrm{-} 10$ $\mu \mathrm{M}$ ), hearts were perfused at a constant flow rate (to give a coronary perfusion pressure of $80 \mathrm{mmHg}$, approximately $10 \mathrm{ml} / \mathrm{min} / \mathrm{g}$ tissue wet weight). For all experiments only one concentration-response curve was performed per heart. At the completion of concentration-response curve, hearts were removed, blotted and weighed. 


\section{The effect of DPMA on coronary vasodilation and contractility.}

Initial studies were performed with the $\operatorname{Ado}_{2} R$ agonist DPMA $(0.1 \mathrm{nM}-10 \mu \mathrm{M})$. The effect of DPMA on $\operatorname{AdoA}_{1} \mathrm{R}$ induced negative inotropic responses are shown in Fig. 1. The $\mathrm{pEC}_{50}$ value for DPMA induced decreases in triple product is $8.36 \pm 0.43(\mathrm{n}=6)$. All further experiments determining the effect of DPMA on $\mathrm{Ado}_{1} \mathrm{R}$ mediated reductions in contractility were performed using the concentration of $1 \mathrm{nM}$, which induced negligible changes in heart contractility ( $6 \pm 4 \%, \mathrm{P}>0.05$ ). The concentration of DPMA causing a maximal vasodilator response with less than a $5 \%$ variation in heart rate (from baseline) was determined (data not shown). From concentration-response curves it was evident maximal relaxation (and therefore pronounced activation of $\mathrm{Ado}_{2} \mathrm{R}$ ) was achieved with $10 \mathrm{nM}$ DPMA, giving a $98 \pm 2 \%$ increase in flow with a $\mathrm{pEC}_{50}$ value of $9.64 \pm 0.15$ ( $\mathrm{n}=6$, data not shown). These results are consistent with $\mathrm{K}_{\mathrm{i}}$ values for DPMA obtained in male Wistar rats of $\sim 350 \mathrm{nM}$ for $\mathrm{Ado}_{1} \mathrm{R}$ binding versus $2 \mathrm{nM}$ for $\mathrm{Ado}_{2} \mathrm{R}$ binding in mouse brain (17).

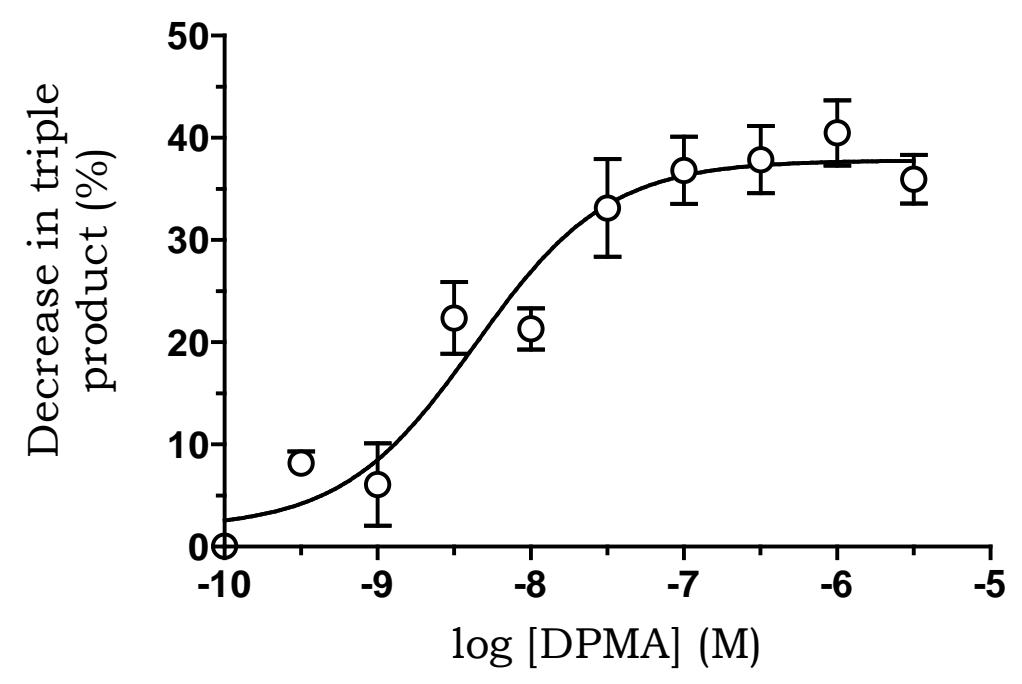




\section{Effect of DPMA on R-PIA induced negative inotropic response.}

The effect of DPMA on Ado $_{1}$ R-mediated inhibition of contractility was examined. The selective $\operatorname{Ado}_{1} \mathrm{R}$ agonist R-PIA $(0.1 \mathrm{nM}-10 \mu \mathrm{M})$ was infused in the presence or absence of $1 \mathrm{nM}$ DPMA. Additional experiments incorporated selective $\mathrm{Ado}_{2} \mathrm{R}$ antagonists. The Ado $\mathrm{A}_{2 \mathrm{~A}} \mathrm{R}$ antagonist 8-(3-chlorostyryl) caffeine (CSC, $\left.1 \mu \mathrm{M}\right)$ or the Ado $\mathrm{A}_{2 \mathrm{~B}} \mathrm{R}$ inhibitor alloxazine ( $\left.3 \mu \mathrm{M}\right)$ was combined with DPMA (1 $\left.\mathrm{nM}\right)$ to study R-PIA induced decreases in triple product. Furthermore, the adenylyl cyclase inhibitor cis-N-(2phenylcyclopentyl)-azacyclotridec-1-en-2-amine hydrochloride (MDL12330A, 100 nM) was added with DPMA (1 nM) and R-PIA concentration-response curves were performed in paced tissues. To show that the antagonists used do not affect Ado $_{1} \mathrm{R}$-mediated inhibition of contractility or paced heart function, concentration-response curves to R-PIA were also completed in the presence of alloxazine, CSC and MDL12330A.

Table 1. Hemodynamic parameters of each treatment group of rat hearts during basal conditions.

Table 1 Haemodynamic parameters for each treatment group under basal conditions

\begin{tabular}{llllll}
\hline & $\begin{array}{c}\text { LVDP } \\
(\mathrm{mmHg})\end{array}$ & $\begin{array}{l}\mathrm{dP}^{2} \mathrm{dt}_{\max } \\
\left(\mathrm{mmHg} \cdot \mathrm{sec}^{-1}\right)\end{array}$ & $\begin{array}{l}\mathrm{dP} / \mathrm{dt}_{\min } \\
\left(\mathrm{mmHg} \cdot \mathrm{sec}^{-1}\right)\end{array}$ & $\begin{array}{l}\mathrm{CPP} \\
(\mathrm{mmHg})\end{array}$ & $\mathrm{N}$ \\
\hline Control & $93 \pm 5$ & $2332 \pm 70$ & $-1874 \pm 58$ & $88 \pm 6$ & 7 \\
DPCPX & $101 \pm 8$ & $1856 \pm 96^{*}$ & $-1830 \pm 115$ & $64 \pm 10$ & 4 \\
DPMA & $74 \pm 8$ & $2729 \pm 198$ & $-1671 \pm 27$ & $52 \pm 6^{*}$ & 6 \\
CSC & $100 \pm 5$ & $2662 \pm 123^{*}$ & $-1767 \pm 108$ & $72 \pm 3$ & 4 \\
Alloxazine & $97 \pm 8$ & $1604 \pm 132^{*}$ & $-1760 \pm 187$ & $80 \pm 7$ & 4 \\
MDL12330A & $102 \pm 9$ & $2523 \pm 212$ & $-1967 \pm 241$ & $69 \pm 5$ & 4 \\
$\begin{array}{l}\text { DPMA \& } \\
\text { CSC }\end{array}$ & $90 \pm 5$ & $2080 \pm 90$ & $-1665 \pm 57$ & $64 \pm 5^{*}$ & 7 \\
$\begin{array}{l}\text { DPMA \& } \\
\text { Alloxazine }\end{array}$ & $78 \pm 3$ & $2039 \pm 232$ & $-1587 \pm 106$ & $63 \pm 3^{*}$ & 7 \\
$\begin{array}{l}\text { DPMA \& } \\
\text { MDL12330A }\end{array}$ & $109 \pm 7$ & $2537 \pm 158$ & $-1766 \pm 227$ & $70 \pm 3^{*}$ & 8 \\
\hline
\end{tabular}


All hearts were paced at $5 \mathrm{~Hz}$. All values are means \pm S.E.M. LVDP, left ventricular developed pressure; $\mathrm{dP} / \mathrm{dt}_{\max }$, first derivative of left ventricular pressure; $\mathrm{dP} / \mathrm{dt}_{\min }$, second derivative of left ventricular pressure $\mathrm{CPP}$, coronary perfusion pressure. *P different from control values $(\mathrm{P}<0.05)$. The concentrations of the agonist / antagonists are as follows: DPCPX, 50 nM; DPMA, 1 nM; CSC, $1 \mu \mathrm{M}$; Alloxazine, $3 \mu \mathrm{M}$; MDL12330A, $100 \mathrm{nM}$;

\section{Data analysis.}

Unless stated otherwise, all values shown are means \pm S.E.M. All data were analysed using a repeated measures ANOVA followed by the Newman-Keuls post hoc test for individual comparisons when significant effects was detected. Concentration-response curves to the DPMA and R-PIA were analysed by nonlinear regression using the program GraphPad Prism ${ }^{\circledR}, \mathrm{EC}_{50}$ and confidence interval (CI) values were derived from these curves. Differences were considered significant at $\mathrm{P}<0.05$.

\section{Materials.}

R-PIA, DPMA, CSC, alloxazine, DPCPX and MDL-12330A were all purchased from Sigma Chemicals (Castle Hill, Australia). DPMA and CSC was added directly to perfusing fluid from $100 \mu \mathrm{M}$ stock (in 1\% DMSO) and diluted to achieve a $10 \mathrm{nM}$ final concentration. DPCPX (0.5 mM) stock was dissolved in DMSO then diluted 1 in 10000 to give a final concentration of $50 \mathrm{nM}$. Dilutions of R-PIA were prepared in buffer from a $0.5 \mathrm{mM}$ stock. Alloxazine stock $(10 \mathrm{mM})$ was dissolved in distilled water with $50 \mu \mathrm{l}$ $\mathrm{NaOH}(10 \mathrm{M})$ and added to the perfusing solution prior to use. MDL 12330A (1 mM)

stock was made up in distilled water and stored in frozen aliquots $\left(-80^{0} \mathrm{C}\right)$ until required. 


\section{Results}

\section{The effect of drug treatments on basal functional parameters in isolated perfused hearts.}

Functional variables under basal conditions are presented in table 1 . LVDP and $\mathrm{dP} / \mathrm{dt}_{\mathrm{min}}$ were comparable in all groups tested. CPP was reduced by $41 \%$ in DMPA treated hearts compared to control hearts $(\mathrm{P}<0.05)$. dP/dt $\max$ was reduced in DPCPX $(50 \mathrm{nM})$ and alloxazine $(3 \mu \mathrm{M})$ treated tissues when compared to untreated controls $(\mathrm{P}<0.05)$. However, in CSC $(1 \mu \mathrm{M})$ treated tissues $\mathrm{dP} / \mathrm{dt}_{\max }$ values were higher than control data $(\mathrm{P}<0.05)$. The combination of DMPA and alloxazine or CSC returned $\mathrm{dP} / \mathrm{dt}_{\max }$ values to control levels.

\section{Effect of adenosine $A_{2}$ receptor activation on adenosine $A_{1}$ receptor-mediated decreases in heart inotropic responses.}

R-PIA induced concentration-dependent reductions in triple product which were inhibited by DPCPX (50 nM, see Table 2). The addition of the Ado $A_{2} R$ agonist DPMA (1 nM) did not alter contractility in paced hearts, as measured by the triple product $(\mathrm{P}<0.05)$. DPMA $(1 \mathrm{nM})$ attenuated maximal decreases in cardiac responses to R-PIA from $48.93 \pm 3.00 \%$ in control tissues compared to $16.94 \pm 6.20 \%$ with DPMA treatment, see table 2 and Fig. 2. 
Table 2. The effect of various antagonists on R-PIA induced decreases in triple product.

\begin{tabular}{|l|c|c|}
\hline & $\mathrm{pEC}_{50} \pm \mathrm{CI}$ & Maximal response (\%) \\
\hline Control & $8.00 \pm 0.51$ & $48.93 \pm 3.00$ \\
\hline DPCPX & $7.00 \pm 0.94^{*}$ & $29.8 \pm 5.67^{*}$ \\
\hline DPMA & $6.30 \pm 1.03^{*}$ & $16.94 \pm 6.20^{*}$ \\
\hline CSC & $7.46 \pm 0.51$ & $51.23 \pm 6.34$ \\
\hline Alloxazine & $7.29 \pm 0.48$ & $47 \pm 1.40$ \\
\hline MDL12330A & $7.49 \pm 0.37$ & $49.26 \pm 3.09$ \\
\hline DPMA + CSC & $7.60 \pm 0.30$ & $45.07 \pm 5.79$ \\
\hline DPMA + Alloxazine & $7.76 \pm 0.52$ & $19.08 \pm 3.19 *$ \\
\hline DPMA + MDL12330A & $7.26 \pm 0.32$ & $33.64 \pm 4.47$ \\
\hline
\end{tabular}

The concentrations of the agonist / antagonists are as follows: DPCPX, 50 nM; DPMA, 1 nM; CSC, $1 \mu \mathrm{M}$; Alloxazine, $3 \mu \mathrm{M}$; MDL12330A, $100 \mathrm{nM}$. pEC 50 represents -logEC $\mathrm{C}_{50}$ values for each R-PIA concentration-response curve with confidence intervals (CI). $* \mathrm{P}<0.05$ vs control, $\mathrm{n}=4-7$ per group.

\section{Effect of inhibitors on adenosine $A_{1}$ receptor-mediated decreases in triple product.}

Addition of CSC $(1 \mu \mathrm{M})$ and DPMA $(1 \mathrm{nM})$ reversed effects of DPMA on R-PIA mediated reductions in contractility (see Fig $3 \mathrm{~A}, \mathrm{P}<0.05$ ). The attenuation of the R-PIA response by DPMA was not altered by co-treatment with alloxazine $(3 \mu \mathrm{M})(\mathrm{P}>0.05$, Fig $3 A)$. These data indicate $A_{d o} A_{2 A} R$ 's are responsible for reducing $\operatorname{Ado}_{1} R$ mediated decreases in inotropic state in rat heart.

The addition of the adenylyl cyclase inhibitor MDL12330A (100 nM) reversed the effect DPMA on the negative inotropic response to R-PIA ( $\mathrm{P}<0.05$, see table 1 and Fig. 3B). 
Use of CSC, alloxazine or MDL12330A alone did not alter R-PIA concentrationresponse curves with $\mathrm{pEC}_{50}$ values or maximal decreases in triple product remaining unchanged (see Table 2).

This data implies that $\mathrm{Ado}_{2} \mathrm{Rs}$ reverse $\mathrm{Ado}_{1} \mathrm{R}$ mediated cardiac responses through stimulation of adenylyl cyclase.

Fig. 2

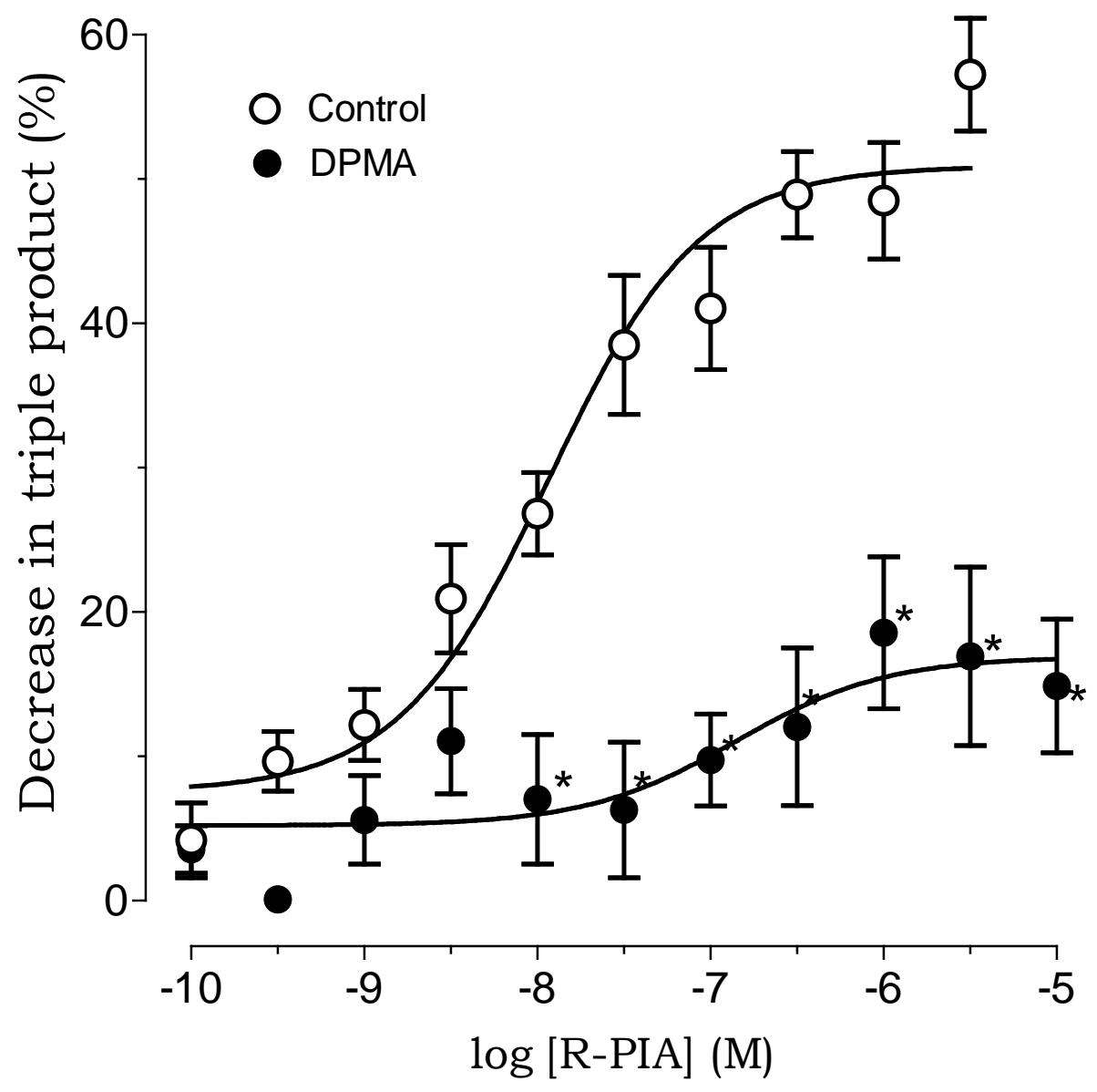


Fig. 3
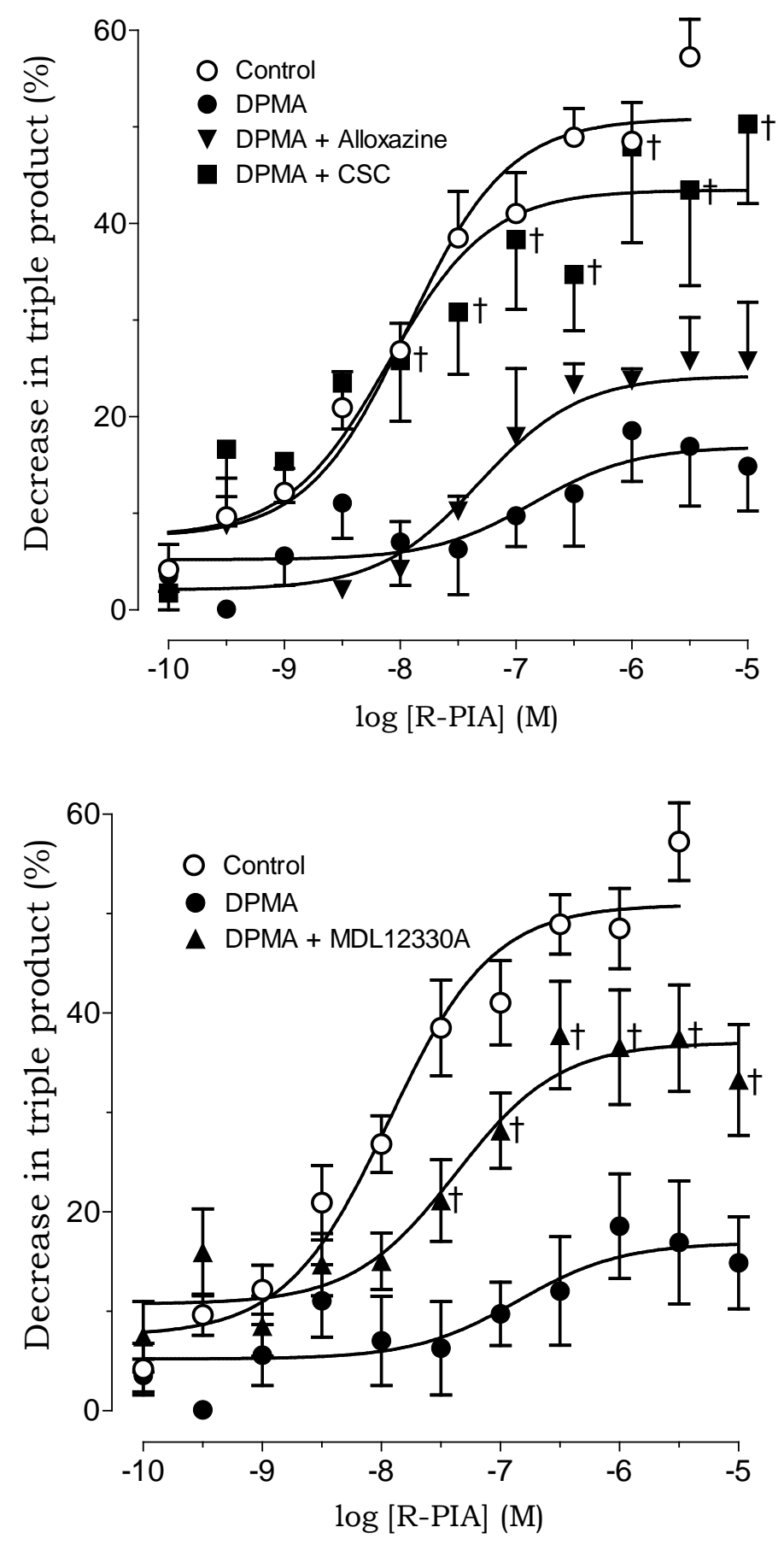


\section{DISCUSSION}

In this study, concentration-response relationships for R-PIA mediated negative inotropy were obtained in rat hearts in the presence and absence of selective concentrations of the Ado $_{2} \mathrm{R}$ agonist, DPMA. DPMA was utilized as it is a non-selective $\mathrm{AdoA}_{2} \mathrm{R}$ agonist that has a much greater relative affinity for the $\operatorname{Ado}_{2} R\left(K_{i}=2 n M\right)$ than for the $\operatorname{Ado}_{1} R\left(K_{i}\right.$ $=350 \mathrm{nM}, 13)$. The purpose of this project was to determine the role of both subtypes of $\mathrm{Ado}_{2} \mathrm{Rs}$ in modifying $\mathrm{AdoA}_{1} \mathrm{R}$ mediated negative inotropic responses in heart. CGS21680 was not employed as it is selective for Ado $_{2 A}$ over Ado $_{2 B} R\left(K_{i}\right.$ value of 19 nM vs. 10 $000 \mathrm{nM}$ at $\mathrm{Ado}_{2 \mathrm{~B}} \mathrm{Rs}$, for review see Muller, 18) and this would have precluded investigations into the potential role of $\operatorname{Ado}_{2 \mathrm{~B}} \mathrm{R}$ in modifying cardiac activities of $A_{d o} A_{1} R$. There are very few selective $A_{d o} A_{2 B} R$ agonists currently available (18). CGS21680 also acts a partial agonist (19) and will alter its binding behaviour in low receptor populations as observed in heart tissue.

Another study has shown that the $\mathrm{AdoA}_{2} \mathrm{R}$ modulates the indirect anti-adrenergic effects of $\mathrm{Ado}_{1} \mathrm{R}$ on contractile function (13). In rat ventricular myocytes, $\mathrm{Ado}_{1} \mathrm{R}$ mediated inhibition of cardiac contractility is associated with activation of inward rectifying $\mathrm{K}^{+}$ current $\mathrm{I}_{\mathrm{K}(\mathrm{Ado})}$ and inhibiting isoproterenol stimulated L-type $\mathrm{Ca}^{2+}$ current (7). The actions of $\mathrm{AdoA}_{1} \mathrm{R}$ are reported to be due to inhibition of adenylyl cyclase (20), or activation of other mediators including nitric oxide and cGMP (21) or phosphoinositide-PKC- $\varepsilon$ (22, 23).

In our study, DPMA significantly attenuated the negative inotropic effects of R-PIA, demonstrating that $\mathrm{Ado}_{2} \mathrm{R}$ modifies $\mathrm{Ado}_{1} \mathrm{R}$-mediated inotropic responses in normoxic 
heart. Use of selective AdoR antagonists indicate that it is the $\operatorname{Ado}_{2 \mathrm{~A}} \mathrm{R}$ subtype that is involved. The Ado $_{2 A} \mathrm{R}$ agonist CGS21680 can increase inotropic responses in isolated myocytes an effect that is mediated by cAMP - dependant and independent mechanisms (24), however, another study has found that although rat ventricular myocytes express Ado $_{2 \mathrm{~A}}$ receptors they do not alter cAMP or contractility (14). AdoA ${ }_{2 B}$ Rs mediate an increase in coronary flow and developed pressure in $\mathrm{Ado}_{2 \mathrm{~A}} \mathrm{R}$ knockout murine hearts (25). Due to multiple AdoRs in cardiac tissue, the physiological role of myocardial Ado $A_{2 B}$ Rs have been difficult to determine and recent investigations have blocked Ado $_{1}$ Rs or deleted Ado $_{2 A} R$ s in order to study cardiac $\operatorname{AdoA}_{2 B} R$ 's $(25,26)$. Our investigations in isolated electrically paced rat hearts indicate that $\mathrm{Ado}_{2 \mathrm{~B}} \mathrm{Rs}$ do not modify $\mathrm{Ado}_{1} \mathrm{R}$ mediated decreases in ventricular contractile function.

Also, in the present study, the adenylyl cyclase inhibitor MDL-12330A (27) was employed to determine whether Ado $_{2 A} R$-mediated attenuation of the negative inotropic effects of Ado $_{1} R$ activation was due to an increase in cAMP levels. In support of this possibility, MDL12330A, reversal of the effect of DPMA on AdoA $\mathrm{A}_{1}$ mediated negative inotropic actions. MDL12330A however, did not completely reverse the effects of DPMA, indicating a possible role for other second messengers to be involved.

In conclusion, the results of the present study demonstrate that $\mathrm{Ado}_{2} \mathrm{R}$ significantly attenuates $\mathrm{AdoA}_{1} \mathrm{R}$ mediated decreases in inotropic state. The adenosine receptor subtype involved in this response is the Ado $\mathrm{A}_{2 \mathrm{~A}} \mathrm{R}$ subtype, and its mechanism of action may involve stimulating adenylyl cyclase activity. This study has revealed a more complex interplay between AdoRs in the control of cardiac physiological function than was previously appreciated. 


\section{References}

1. Belardinelli L, Linden J, Berne RM. The cardiac effect of adenosine. Prog Cardiovasc Dis 1989; 32 (1): 73-97.

2. Olsson RA. Adenosine receptors in the cardiovascular system. Drug Dev Res 1996; 39: 301-307.

3. de Jong JW, de Jong R, Keijer E, Bradamante S. The role of adenosine in preconditioning. Pharmacol Ther 2000; 87 (2-3): 141-149.

4. Belardinelli L, Shyrock JC, Snowdy S, et al. The $\mathrm{A}_{2 \mathrm{~A}}$ adenosine receptor mediates coronary vasodilation. J Pharm Exp Ther 1998; 284: 1066-1073.

5. Hinschen AK, Rose'Meyer RB, Headrick JP. Adenosine receptor subtypes mediating coronary vasodilation in rat hearts. J Cardiovasc Pharm 2003; 41: 73-80.

6. Song Y, Belardinelli L. Electrophysiological and functional effects of adenosine on ventricular myocytes of various mammalian species. Am J Physiol (Cell Physiol) 1996; 271: C1233-1243.

7. Stein B, Schmitz W, Scholz H. Seeland C. Pharmacological characterisation of $\mathrm{A}_{2^{-}}$ adenosine receptors in guinea-pig ventricular cardiomyocytes. J Mol Cell Cardiol 1994; 26: 403-414.

8. Kitakaze M, Hori M, Kamada T. Role of adenosine and its interaction with alpha adrenoceptor activity in ischaemic and reperfusion injury of the myocardium. Cardiovasc Res 1993; 27: 18-27.

9. Talukder MAH, Morrison RR, Jacobson MA, et al. Targeted deletion of adenosine $\mathrm{A}_{3}$ receptors augments adenosine-induced coronary flow in isolated mouse heart. Am J Physiol (Heart Circ Physiol) 2002; 282; H2183-H2189. 
10. Hinschen AK, Rose'Meyer RB, Headrick JP. Age-related changes in $\mathrm{A}_{1}$-adenosine receptor-mediated bradycardia. Am J Physiol (Heart Circ Physiol) 2000; 278: H789-H795.

11. Schreieck J, Richardt G. Endogenous adenosine reduces the occurrence of ischemia-induced ventricular fibrillation in rat heart. J Mol Cell Cardiol 1999; 31(1): 123-134.

12. Liang BT, Haltiwanger B. Adenosine A2a and A2b receptors in cultured fetal chick heart cells. Circ Res 1995; 76: 242-251.

13. Norton GR, Woodiwiss AJ, McGinn RJ, et al. Adenosine $A_{1}$ receptor-mediated antiadrenergic effects are modulated by $\mathrm{A}_{2 \mathrm{a}}$ receptor activation in rat heart. $\mathrm{Am} J$ Physiol (Heart Circ Physiol) 1999; 276(45); H341-H349.

14. Kilpatrick EL, Narayan P, Mentzer RM Jr. Lasley RD. Cardiac myocytes adenosine $A_{2 a}$ receptor activation fails to alter cAMP or contractility: role of receptor localization. Am J Physiol (Heart Circ Physiol) 2002; 282: H1035-1040.

15. Dixon AK, Gubitz A, Sirinathsingji DJS Richardson PJ, Freeman TC. Tissue distribution of adenosine receptor mRNAs in the rat. Brit J Pharmacol 1996; 118: $1461-1468$.

16. Harrison GJ, Harden FA, Jordan LR, Varela JI, Willis RJ. A method to evaluate the response of the coronary circulation of perfused rat heart to adenosine. Can $J$ Physiol Pharmacol 1996; 74: 145-149.

17. Klitgaard H, Knutsen JS, Thomsen C. Contrasting effects of adenosine $A_{1}$ and $A_{2}$ receptor ligands in different chemoconvulsive rodent models. Eur J Pharmacol 1993; 242: 221-228. 
18 Muller CE. Adenosine receptor ligands-recent developments Part 1. Agonists. Curr Med Chem 2000; 7: 1269-1288.

19. Prentice DJ, Hourani SMO. Activation of multiple sites by adenosine analogues in the rat isolated aorta. Brit J Pharmacol 1996; 118(6): 1509-17.

20. Romano FD, MacDonald SG, Dobson JG. Adenosine receptor coupling to adenylate cyclase of rat ventricular myocytes membranes. Am J Physiol (Heart Circ Physiol) 1989; 57: H1088-H1095.

21. Sterin-Borda L, Gomez RM, Borda E. Role of nitric oxide/ cyclic GMP in myocardial adenosine $A_{1}$ receptor-inotropic response. Brit J Pharmacol 2002; 135: 444-4506.

22. Lester JW, Gannaway KF, Reardon RA Koon LD, Hofmann PA. Effects of adenosine and protein kinase $\mathrm{C}$ stimulation on mechanical properties of rat cardiac myocytes. Am J Physiol (Heart Circ Physiol) 1996; 271: H1778-H1785.

23. Lester JW, Hofmann PA. Role for PKC in the adenosine-induced decrease in shortening velocity of rat ventricular myocytes. Am J Physiol (Heart Circ Physiol) 2000; 279: H2685-H2693.

24. Dobson JG, Fenton RA. Adenosine $A_{2}$ receptor function in rat ventricular myocyctes. Cardiovasc Res 1997; 34: 337-347.

25. Morrison RR, Talukder MAH, Ledent C, Mustafa SJ. Cardiac effects of adenosine in $\mathrm{A}_{2 \mathrm{~A}}$ receptor knockout hearts: uncovering $\mathrm{A}_{2 \mathrm{~B}}$ receptors. Am J Physiol (Heart Circ Physiol) 2002; 282: H437-H444.

26. Feoktistov I, Biaggioni I. Adenosine $A_{2 B}$ receptors. Pharm Rev 1997; 49(4): 381402. 
27. Koh HC, Lee TK, Kang JS, et al. Modification of cardiovascular response of adenosine $A_{2}$ receptor agonist by adenylate cyclase in the spinal cord of rats. Neurosci Lett 2000; 293: 45-48. 


\section{Figure legends}

Fig. 1. Concentration-response curve to DPMA on triple product (heart rate $\mathrm{x} d \mathrm{P} / \mathrm{dt}_{\max } \mathrm{x}$ PSVP) in isolated perfused hearts paced at $5 \mathrm{~Hz}$ (5 ms duration, supramaximal voltage) $(n=5)$. All values represent mean \pm SEM.

Fig. 2. Concentration-response curves to R-PIA on triple product (heart rate $x \mathrm{dP} / \mathrm{dt}_{\max } \mathrm{x}$ PSVP) in isolated perfused hearts paced at $5 \mathrm{~Hz}$ (5 ms duration, supramaximal voltage) in the absence $(O, n=7)$ and the presence of DPMA $(10 n M, \bullet, n=6)$. Values represent mean \pm SEM. $* \mathrm{P}<0.05$ vs. control.

Fig. 3. Panel A; The effects of chlorostyryl caffeine (CSC, $1 \mu \mathrm{M}, \mathbf{\square}, \mathrm{n}=4$ ) or alloxazine $(3 \mu \mathrm{M}, \boldsymbol{\nabla}, \mathrm{n}=4)$ and DPMA $(1 \mathrm{nM})$ on concentration-response curves to R-PIA on triple product (heart rate $\mathrm{x} \mathrm{dP} / \mathrm{dt}_{\max } \mathrm{x}$ PSVP) in isolated perfused hearts paced at $5 \mathrm{~Hz}(5 \mathrm{~ms}$ duration, supramaximal voltage). $\uparrow \mathrm{P}<0.05$ vs. DPMA treated data. Panel B; The effects of MDL12330A (100 nM, ^ , $\mathrm{n}=5$ ) and DPMA (1 nM) on concentration-response curves to R-PIA on triple product (heart rate $\mathrm{x} \mathrm{dP} / \mathrm{dt}_{\max } \times \mathrm{PSVP}$ ) in isolated perfused hearts paced at $5 \mathrm{~Hz}$ (5 ms duration, supramaximal voltage). Values represent mean \pm SEM. $† \mathrm{P}<0.05$ vs. DPMA treated data. 